\title{
OPTIMALISASI LATIHAN RELAKSASI OTOT PROGRESIF BERPENGARUH TERHADAP PENURUNAN TINGKAT KECEMASAN PADA LANSIA
}

\author{
Nungki Marlian Yuliadarwati", Nur Hikmah, Siti Ainun Ma'rufa \\ Program Studi Fisioterapi, Fakultas Ilmu Kesehatan, Unversitas Muhammadiyah Malang \\ *Korespondensi : nungki@umm.ac.id
}

\begin{abstract}
ABSTRAK
Kesehatan pada lanjut usia didasari oleh aspek fisik, sosial, ekonomi dan psikologis yang menyebabkan mudah tersinggung, kemunduran fisik terutama kesehatan seperti musculoskeletal, kardiovaskular, perasaan tidak berguna yang mentebabkan terjadinya kecemasan yang dapat diselesaiakan dengan metode relaksasi otot progresif. Untuk mengetahui pengaruh metode relaksasi otot progresif terhadap tingkat kecemasan pada lanjut usia. Penelitian pre-eksperimen dengan model pendekatan pre-test posttest one group design dengan alat pengukuran tingkat stres Hamilton Anxiety Rating Scale (HARS). Hasil analisis uji Paired t-test diperoleh hasil signifikansi 0,000 ( $p<0,05)$ maka dari hasil tersebut dapat disimpulkan bahwa Ho ditolak dan Ha diterima. Terdapat pengaruh latihan relaksasi progresif terhadap penurunan tingkat kecemasan pada lanjut usia.
\end{abstract}

Kata Kunci: Relaksasi otot progresif, Lanjut usia, Kecemasan

\section{PENDAHULUAN}

Permasalahan kehidupan pada lansia dapat disebabkan oleh beberapa faktor kesehatan seperti sosial fisik, ekonomi dan psikologi yang dapat menyebabkan kekecewaan, tersinggung dan tidak percaya diri dari segi fisik menurun terutama kesehatan lanjut usia dari sistem kardiovaskular, musculoskeletal. (Ari 2010).

Dari penelitian BPS RI Susenas tahun 2016 menyatakan bahwa penduduk lansia dari berbagai provinsi, presentase penduduk lansia didata $10 \%$ terdapat di provinsi Daerah Istimewa Yogyakarta (14,02\%), Jawa Tengah (10,99\%), Jawa Timur
$(10,92 \%)$, dan Bali $(10,79 \%)$ (Komnas Lansia, 2016 dalam Tasia, 2018). Kecemasan pada lanjut usia didapat hasil sebanyak 17,6\% yang ada di salah satu penelitian di Amerika. Wolitzky tahun 2010 menyatakan pada lanjut usia terdapat prevalensi gangguan kecemasan, betambah dari $3,2 \%$ ke $14,2 \%$.

Peningkatan angka kejadian kecemasan pada lansia yang terus bertambah menyebabkan kondisi kesehatan semakin menurun dan akan menyebabkan ansietas merupakan kondisi yang umum paling sering disertai dengan perasaan takut dengan sensasi fisik antara lain nafas pendek jantung berdebar dan nyeri dada. 
Tingkat kecemasan disebabkan karena adanya keluhan di otak yang berkaitan dengan keluhan kejiwaan atau keluhan fisik (Keliat, 2011).

Ahsan dan Arik tahun 2015 menyatakan kecemasan atau ansietas mempunyai dua aspek yang dapat menyehatkan dan membahayakan tergantung pada koping individu dan tingkat lama kecemasan yang dialami. Stuart tahun 2007 dalam Sulistyorini, Ahsan dan Arik tahun 2015 menyatakan bahwa kecemasan dapat menyebabkan ketidakseimbangan sosial, fisik dan psikologi. Ketidakseimbangan fisik berupa keluhan-keluhan somatik seperti terjadinya peningkatan ketegangan otot, tekanan darah, insomnia, dan palpitasi dan disertai aktivitas saraf otonom.

Peran Fisioterapi dalam menyeimbangkan keluhan somatik adalah metode terapi latiham dengan Latihan relaksasi ini yaitu latihan relaksasi yang menggunakan otot dalam yang tidak menggunakan sugesti, imajinasi, atau ketekunan. Latihan ini mengarahkan pada gerakan otot dengan mengenali otot yang tegang kemudian menurunkan ketegangan dengan melakukan teknik relaksasi otot progresif untuk mendapatkan efek relaksasi (Herodes, 2010, dalam Kushariyadi, 2011)

Pengaruh dari latihan relaksasi otot progresif adalah serabut saraf parasimpatis akan aktif dan mengaktifkan hormon endorphin yang berfungsi untuk mendapatkan efek senang atau bahagia dan mengembalikan tubuh ke kondisi normal sehingga terjadi relaks pada otot-otot tersebut dan terjadi penurunan kecemasan dan stres (Videback, 2008). Latihan ini dengan dosis 1 kali sehari dilakukan dalam
7 hari berturut-turut efektif untuk penurunan tingkat kecemasan (Annisa, Heppy dan Purnomo, 2016).

\section{METODE PENELITIAN}

metode penelitian menggunakan pra eksperimental dan rancangan one group pre-test post-test design dengan satu intervensi, dengan melakukan pengamatan sebelum diberikan pre-test, kemudian diamati lagi setelah diberikan post-test (Nursalam, 2008). Pengukuran skala tingkat kecemasan yaitu HARS (Hamilton Anxiety Rating Scale), kemudian melakukan post-test dengan diberikan intervensi, lalu diukur kembali menggunakan skala Hamilton Anxiety Rating Scale (HARS).

\section{HASIL}

Optimalisasi Latihan Relaksasi otot progresif untuk tingkat kecemasan lansia di lakukan penelitian selama empat minggu dan dimulai pada bulan April, dan Mei 2019, dan 32 sampel. Kemudian 32 sampel diberikan intervensi latihan yang dilakukan 3 kali seminggu dalam satu bulan. Dosis setiap latihan yang diberikan delapan kali hitungan dengan tiga repetisi (Igweonu, 2010).

Hasil analisis statistik dengan uji Paired $t$-test diperoleh $\mathrm{P}=0,000<\alpha=0,05$, dapat disimpulkan bahwa ada pengaruh latihan Relaksasi otot progresif terhadap tingkat kecemasan lansia

\section{PEMBAHASAN}

Latihan relaksasi otot progresif dapat menghentikan peningkatan saraf simpatis serta mempunyai efek sensasi menenangkan anggota tubuh, ringan serta 
merasa kehangatan yang dapat menyebar ke seluruh tubuh. Perubahan-perubahan yang terjadi selama maupun setelah relaksasi mempengaruhi kerja saraf otonom. Respon emosi serta efek menenangkan yang ditimbulkan oleh relaksasi ini mengubah fisiologi dominan sistem parasimpatis, dalam keadaan ini terjadi hipersekresi katekolamin serta kortisol diturunkan dan meningkatkan hormon endorphin yang diaktifkan oleh saraf parasimpatis serta neurotransmitter seperti DHEA (Dehidroepinandrosteron) dan dopamine (Puji dan Yuswiyanti, 2015)

Sistem parasimpatis memiliki berbagai fungsi kerja yang berbeda dari saraf simpatis, hal ini dapat menurunkan atau memperlambat internal tubuh, dan pada akhirnya terdapat penurunan detak jantung, irama nafas, ketegangan otot, tekanan darah, metabolisme serta produksi hormon yang mana penyebab dari kecemasan (Annisa, Heppy dan Purnomo, 2015)

Dewa dan Made tahun (2012) menyatakan bahwa pada latihan relaksasi otot progresif pada gerakan tertawa ada 15 otot wajah yang berkontraksi dan mendapatkan rangsangan dari banyaknya otot mulut. Terdapat suatu dorongan ketika bibir terbuka dan tertutup, untuk menghirup dan mengambil banyak oksigen, yang disebarkan ke seluruh tubuh dalam total yang lebih banyak di sistem peredaran darah dan dapat membagikan efek pada suhu diotak yang berfungsi menyegarkan otak kembali, hal ini dapat berefek pada pengeluaran neutrasmiter yaitu hormon endorphin, melatonin dan serotonin yang berfungsi membawa keadaan emosi dan perasaan ke seluruh tubuh sehingga terjadi penurunan emosi dan kecemasan.

\section{KESIMPULAN}

Berdasarkan hasil yang diperoleh dan penjelasan di atas, dapat disimpulkan bahwa ada pengaruh latihan relaksasi otot progresifterhadap kecemasan lansia. Diharapkan peneliti memperbanyak sampel dalam penelitian. Penelitian ini juga dapat digunakan sebagai literatur atau sumber untuk penelitian masa depan.

\section{SARAN}

Peneliti selanjutna dengan judul yang sama atau mengembangkan dengan kombinasi atau melanjutkan penelititian serupa. Dapat memperluas populasi dan menggunakan beberapa instrumen yang digunakan untuk pengukuran kecemasan pada lansia yang bertujuan untuk membuktikan keilmuan dan pengaruh latihan relaksasi otot progresif, Selain itu latihan relaksasi otot progresif dapat ditindak lanjuti sebagai aktifitas yang dapat meningkatkan kebugaran lansia sehingga usia harapan hidup lansia lebih panjang.

\section{DAFTAR PUSTAKA}

Annisa, E.Q., Heppy, R.D dan Purnomo. (2015). Pengaruh Relaksasi Otot Progresif Terhadap Kecemasan Lansia Di Panti Werdha Harapan Ibu Semarang Barat. Jurnal Ilmu Keperawatan dan Kebidanan

Ari, P.LD. (2010). Pengaruh Relaksasi Progresif Terhadap Tingkat Kecemasan Pada Pasien Skizofrenia di Rumah Sakit Jiwa. Surakarta. $\quad$ https://publikasi ilmiah.ums.ac.id/ bit stream/ handle/ 11617/3644/purwaningtyas - arum \%20 pratiwi \%20 fix \%20 bnget.pdf?sequence $=1$, diperoleh 10 November 2018 
Badan Pusat Statistik. (2016). Statistik Penduduk Lanjut Usia. Survei Sosial Ekonomi Nasional (Susenas). Jakarta: BPS

Dewa, I.M.R dan Made, N.D.W. (2012). Pengaruh Pemberian Terapi Tertawa Terhadap Tingkat Kecemasan Pada Lanjut Usia di PSTW Wan Aseraya Denpasar. Dosen Jurusan Keperawatan Poltekkes Denpasar

Puji, L dan Yuswiyanti, A. (2015). Pengaruh Relaksasi Otot Progresif Terhadap Penurunan Tingkat Kecemasan Pada Pasien Pre Operasi di Ruang Wijaya Kusuma RSUD Dr. R Soeprapto Cepu. Jurnal Keperawatan Maternitas

Tasia, P.N.D. (2018). Perbandingan Pengaruh Tandem Walking Exercise Dan Retrowalking Terhadap Keseimbangan Tubuh Pada Lanjut Usia Di Desa Bunulrejo Malang. Skripsi. Universitas Muhammadiyah Malang

Wolitzky-Taylor, K.B, dkk. (2010). Anxiety Disorders In Olders Adults: A Comprehensive Review. Depression An Anxiety 